НАУКОВИЙ ВІСНИК

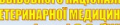

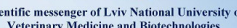
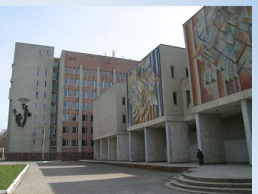

СЕРЯ: ВЕТЕРИНАРН НАУКИ
Науковий вісник Дьвівського національного університету ветеринарної медицини та біотехнологій імені С.3. Гжицького. Серія: Ветеринарні науки

Scientific Messenger of Lviv National University of Veterinary Medicine and Biotechnologies. Series: Veterinary sciences

UDC 619:636.2

\title{
Influence of "Metisevit" feed additive and liposomal preparation "Lipointersil" on the level of vitamins in the blood of bulls at experimental chronic cadmium toxicosis
}

Yu. Yu. Lavryshyn ${ }^{1}$, B. V. Gutyj ${ }^{1}$, M. I. Zhyla ${ }^{2}$, L. V. Kurylas ${ }^{2}$, V. Ya. Prysiazhniuk ${ }^{1}$, I. I. Khariv ${ }^{1}$, V. V. Voroniak ${ }^{1}$

${ }^{I}$ Stepan Gzhytskyi National University of Veterinary Medicine and Biotechnologies Lviv, Ukraine

${ }^{2}$ State scientific research control institute of veterinary preparations and feed additives, Lviv, Ukraine

Article info

Received 13.10.2020

Received in revised form 12.11.2020

Accepted 13.11.2020

Stepan Gzhytskyi National University of Veterinary Medicine and Biotechnologies Lviv,

Pekarska Str., 50, Lviv,

79010, Ukraine.

Tel.:+38-098-861-21-27

E-mail: iylia25071992@gmail.com

State Scientific-Research Control Institute of Veterenary Medicinal Products and Feed Additives, Donetska Str., 11, Lviv, 79019, Ukraine.
Lavryshyn, Yu. Yu., Gutyj, B. V., Zhyla, M. I., Kurylas, L. V., Prysiazhniuk, V., Ya., Khariv, I. I., \& Voroniak, V. V. (2020). Influence of "Metisevit" feed additive and liposomal preparation "Lipointersil" on the level of vitamins in the blood of bulls at experimental chronic cadmium toxicosis. Scientific Messenger of Lviv National University of Veterinary Medicine and Biotechnologies. Series: Veterinary sciences, 22(100), 88-93. doi: 10.32718/nvlvet10016

The article presents the results of research on the effect of feed additive "Metisevit" and liposomal drug "Lipointersil" on the level of vitamins in the blood of bulls in experimental chronic cadmium toxicosis. The research was conducted on the basis of a farm in the village of Ivanivtsi, Zhydachiv district, Lviv region, on 15 bulls of six months of age, Ukrainian black-spotted dairy breed, which were formed into 3 groups of 5 animals each: control and two experimental groups. The bulls of the control group were fed cadmium chloride at a dose of $0.04 \mathrm{mg} / \mathrm{kg}$ body weight for 30 days. The bulls of the first experimental group were fed cadmium chloride at a dose of $0.04 \mathrm{mg} / \mathrm{kg}$ body weight for 30 days and fed a dietary supplement "Metisevit" at a dose of $0.36 \mathrm{~g} / \mathrm{kg}$ of feed. The bulls of the second experimental group were fed cadmium chloride at a dose of $0.04 \mathrm{mg} / \mathrm{kg}$ body weight for 30 days and fed a dietary supplement "Metisevit" in the above dose. On the first and seventh days of the experiment, bulls of this experimental group were injected intramuscularly with liposomal drug "Lipointersil" at a dose of $5 \mathrm{ml}$ per animal. The composition of the liposomal drug "Lipointersil" includes interferon and milk thistle. In the study of the non-enzymatic part of the antioxidant system of the body of bulls under cadmium load found a decrease in vitamins $A$ and $E$. The use of feed additive "Metisevit" increased the content of vitamin E in the blood of bulls of the second experimental group by $10.5 \%$ experiment - by $37.9 \%$ relative to the control group. With the additional use of liposomal drug "Lipointersil" in the blood of bulls found a more likely increase in vitamin E levels throughout the experiment than in the second experimental group, where respectively on the 15th and 20th day of the experiment, this figure increased by 35.3 and $55.1 \%$. The increase in the content of vitamin E in the blood of experimental animals is due to the feeding of the feed supplement "Metisevit", which contains this vitamin. A similar increase is observed in the study of vitamin A in the blood of bulls of experimental groups. It was found that when using a feed additive and liposomal preparation for bulls, on the 15th day of the experiment the level of vitamin $A$ in the blood of the first experimental group increased by $19.4 \%$, and in the blood of the second experimental group - by $26.9 \%$ relative to the control group. Thus, the use of feed supplement "Metisevit" and liposomal drug "Lipointersil" for bulls, which are under conditions of cadmium load, helped to increase the non-enzymatic system of antioxidant protection, namely vitamins $A$ and $E$.

Key words: toxicology, cadmium, vitamins, bulls, feed additive, liposomal preparation.

\section{Вплив кормової добавки “Метісевіт" та ліпосомального препарату “Ліпоінтерсил” на рівень вітамінів у крові бугайців за експериментального хронічного кадмієвого токсикозу}




\author{
Ю. Ю. Лавришин ${ }^{1}$, Б. В. Гутий ${ }^{1}$, М. І. Жила ${ }^{2}$, Л. В. Курилас ${ }^{2}$, В. Я. Присяжнюк ${ }^{1}$, I. І. Харів ${ }^{1}$, \\ В. В. Вороняк ${ }^{1}$
}

${ }^{1}$ Львівський національний університет ветеринарної медицини та біотехнологій імені С. З. Гюсицкого, м. Львів, Украӥна

${ }^{2}$ Держсавний науково-дослідний контрольний інститут ветеринарних препаратів та кормових добавок, м. Львів, Україна

У статті наведено результати досліджень впливу кормової добавки “Метісевіт” та ліпосомального препарату “Ліпоінтерсил” на рівень вітамінів у крові бугайців за експериментального хронічного кадмієвого токсикозу. Дослідження проводились на базі фермерського господарства с. Іванівиі Жидачівського району Львівської області на 15 бугайиях шестимісячного віку, української чорно-рябої молочної породи, які були сформовані у 3 групи по 5 тварин у кожній: контрольну та дві дослідні групи. Бугайиям контрольної групи протягом 30 діб згодовували з комбікормом кадмію хлорид у дозі 0,04 мг/кг маси тіла. Бугайцям першої дослідної групи протягом 30 діб згодовували кадмію хлорид у дозі 0,04 мг/кг маси тіла та задавали до раціону кормову добавку "Метісевіт" у дозі 0,36 г/кг корму. Бугайиям другої дослідної групи з кормом протягом 30 діб згодовували кадмію хлорид у дозі 0,04 мг/кг маси тіла та задавали до раціону кормову добавку «Метісевіт» у вище вказаній дозі. На периу і сьому добу досліду бугайцям даної дослідної групи внутрішньом'язово вводили ліпосомальний препарат “Ліпоінтерсил” у дозі 5 мл на тварину. До складу ліпосомального препарату “Ліпоінтерсил" входить інтерферон та розторопша плямиста. При дослідженні неензимної ланки антиоксидантної системи організму бугайців за кадмієвого навантаження встановлено зниження вмісту вітамінів $A$ i E. Застосування кормової добавки “Метісевіт” сприяло підвищенню вмісту вітаміну Е у крові бугаиів другої дослідної групи на 10 добу досліду на 10,5\%, а на 20 добу досліду - на 37,9\% відносно показників контрольної групи. За додаткового застосування ліпосомального препарату “Ліпоінтерсил” у крові бугайців встановлено більш вірогідніше збільшення рівня вітаміну Е протягом усього експерименту ніж у другої дослідної групи, де відповідно на 15 і 20 добу досліду даний показник збільшився на 35,3 і 55,1\%. Підвищення вмісту вітаміну Е у крові дослідних тварин зумовлено згодовуванням кормової добавки “Метісевіт”, яка у своєму складі містить даний вітамін. Аналогічне підвищення спостерігаємо і при дослідженні вмісту вітаміну А у крові бугайців дослідних груп. Встановлено, що при застосуванні кормової добавки і ліпосомального препарату бугайщям, на 15 добу досліду рівень вітаміну А у крові першої дослідної групи збільшився на 19,4\%, а у крові другої дослідної групи - на 26,9\% відносно контрольноі групи. Отже, застосування кормової добавки “Метісевіт” та ліпосомального препарату “Ліпоінтерсил” бугайцям, які знаходяться в умовах кадмісвого навантаження, сприяли підвищенню неензимної системи антиоксидантного захисту, а саме вітамінів A i E.

Ключові слова: токсикологія, Кадмій, вітаміни, бугайці, кормова добавка, ліпосомальний препарат.

\section{Вступ}

Останніми роками велика увага приділяється вивченню впливу негативних факторів навколишнього середовища на стан здоров'я сільськогосподарських тварин (Gutyj et al., 2016). Серед шкідливих екзогенних факторів, що негативно впливають на організм тварин за даними багатьох дослідників негативну роль відіграє Кадмій як пріоритетний забруднювач навколишнього середовища (Uetani et al., 2005; Pavan Kumar \& Prasad, 2004; Nazaruk et al., 2015).

Проблема вивчення впливу важких металів $є$ особливо актуальною в Україні, де кількість забруднень,

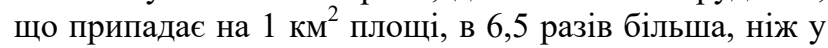
США, та в 3,2 разів більша, ніж у Європейському економічному союзі. Також варто зазначити, що з усіх металів періодичної системи хімічних елементів Кадмій $є$ одним із найшкідливіших. Основними джерелами забруднення атмосфери даним елементом $є$ викиди теплоенергетичних підприємств, заводів 3 переробки відходів та газоподібні викиди чорної і кольорової металургіï (Honskyy et al., 2001; Hutyi, 2013; Peng et al., 2015).

Механізм основної токсичної дії Кадмію обумовлений його токсичною дією на печінку та здатністю посилювати вільнорадикальне окиснення при одночасному окисненні сульфгідрильних груп протеїнів (Ali et al., 1986; Fregoneze et al., 1997; Rodríguez et al., 2001). Різні форми перебігу кадмієвих токсикозів у лабораторних тварин достатньо вивчені, узагальнені, а результати досліджень опубліковані у науковій лі- тературі вітчизняних, і зарубіжних авторів (Salvatori et al., 2004; Lu et al., 2005; Liu et al., 2008; Gutyj et al., 2015; 2017). У літературі зустрічаються дані про вплив Кадмію на морфологічні і біохімічні показники крові молодняку великої рогатої худоби, а також на стан імунної системи (Hutyi, 2013; Lavryshyn et al., 2020). Проте, досі залишається нерозкритим роль вітамінів А і Е у розвитку хронічного кадмієвого токсикозу у молодняку великої рогатої худоби та вплив препаратів на основі рослинної сировини на ці процеси. Тому актуальним на сьогодні $\epsilon$ вивчення питання впливу Кадмію на одну з основних захисних систем організму - антиоксидантну, а саме неензимну ланку.

Метою роботи було дослідити вплив кормової добавки "Метісевіт" та ліпосомального препарату “Ліпоінтерсил” на рівень вітамінів у крові бугайців за експериментального хронічного кадмієвого токсикозу.

\section{Матеріал і методи досліджень}

Дослідження проводились на базі фермерського господарства с. Іванівці Жидачівського району Львівської області на 15 бугайцях шестимісячного віку, української чорно-рябої молочної породи, які були сформовані у 3 групи по 5 тварин у кожній: контрольну та дві дослідні групи. Бугайцям контрольної групи протягом 30 діб згодовували з комбікормом кадмію хлорид у дозі 0,04 мг/кг маси тіла. Бугайцям першої дослідної групи протягом 30 діб згодовували кадмію хлорид у дозі 0,04 мг/кг маси тіла та задавали до раціону кормову добавку "Метісевіт" у дозі 
0,36 г/кг корму (ТУ У 10.9-00492990-004:2014 Кормова добавка "Метісевіт"). Кормову добавку "Метісевіт" було розроблено на кафедрі фармакології та токсикології Львівського національного університету ветеринарної медицини та біотехнологій імені C. 3. Гжицького, яка у своєму складі містить вітамін Е, Селен та метіфен (метіонін, фенарон, цеоліт). Бугайцям другої дослідної групи 3 кормом протягом 30 діб згодовували кадмію хлорид у дозі 0,04 мг/кг маси тіла та задавали до раціону кормову добавку "Метісевіт" у вище вказаній дозі. На першу і сьому добу досліду бугайцям даної дослідної групи внутрішньом'язово вводили ліпосомальний препарат “Ліпоінтерсил” у дозі 5 мл на тварину. До складу ліпосомального препарату “Ліпоінтерсил” входить інтерферон та розторопша плямиста.

Для проведення досліджень дотримувалися правил, обов'язкових з виконання зоотехнічних дослідів щодо підбору та утримання тварин-аналогів у групи, технології заготівлі, використання й обліку спожитих кормів. Раціон тварин був збалансований за поживними та мінеральними речовинами, які забезпечували їх потребу в основних елементах живлення.

Утримання, годівлю, догляд та усі маніпуляції з тваринами здійснювали згідно з Європейською конвенцією "Про захист хребетних тварин, які використовуються для експериментальних і наукових цілей" (Страсбург, 1986 р.) і “Загальних етичних принципів експериментів на тваринах”, ухвалених Першим Національним конгресом 3 біоетики (Київ, 2001). Експерименти проводили 3 дотриманням принципів гуманності, викладених у директиві Свропейської Спільноти.

Дослід тривав упродовж 30-и діб. Кров для аналізу брали з яремної вени на 1-, 5-, 10-, 15-, 20-, і 30-у добу досліду.

Вміст вітамінів А і Е у крові тварин визначали за допомогою високоефективної рідинної хроматографії на хроматографі “Міліхром-4” (Vlizlo, 2012).
Аналіз результатів досліджень проводили за допомогою пакету програм Statistica 6.0. Вірогідність різниць оцінювали за t-критерієм Стьюдента. Результати середніх значень вважали статистично вірогідними при * - $\mathrm{P}<0,05, * *-\mathrm{P}<0,001$ (ANOVA)

\section{Результати та їх обговорення}

Важливу роль у функціонуванні організму й регуляції метаболічних процесів за різних негативних чинників відіграють вітаміни (Khariv et al., 2016; Martyshuk et al., 2016). Варто зазначити, що вітаміни А i E підвищують адаптивні механізми в організмі тварин, протидіють утворенню великої кількості вільних радикалів стимулюючи активність системи антиоксидантного захисту, а при їх дефіциті пригнічується імунний статус (Slobodian et al., 2019; 2020; Ostapyuk \& Gutyj, 2020).

За умов кадмієвого навантаження у крові бугайців контрольної групи встановлено незначне підвищення вітаміну Е у їх крові на 1 та 5 доби досліду. У подальшому відмічаємо зниження рівня вітаміну Е у крові бугайців за кадмієвого навантаження (табл. 1).

Найнижчий рівень вітаміну Е був у крові контрольної групи тварин на 20 добу досліду, де відповідно він становив 2,9 \pm 0,10 мкмоль/л, що на 27,5 \% відносно початкових величин.

При згодовуванні кормової добавки "Метісевіт" бугайцям першої дослідної групи встановлено підвищення рівня вітаміну Е у їх крові на 10 добу досліду на $10,5 \%$, а на 20 добу досліду - на 37,9 \% відносно показників контрольної групи.

При додатковому застосуванні ліпосомального препарату “Ліпоінтерсил” у крові бугайців другої дослідної групи встановлено збільшення рівня вітаміну Е протягом усього досліду. На 15 і 20 добу експерименту рівень вітаміну Е вірогідно збільшився на 35,3 і 55,1 \% відносно контрольних величин.

\section{Таблиця 1}

Вплив метісевіту та ліпоінтерсилу на рівень вітаміну Е у крові бугайців за хронічного кадмієвого токсикозу $(\mathrm{M} \pm \mathrm{m}, \mathrm{n}=5)$

\begin{tabular}{cccc}
\hline \multirow{2}{*}{ Час дослідження крові } & \multicolumn{3}{c}{ Вітамін Е (мкмоль/л) } \\
\cline { 2 - 4 } (доби) & Контрольна & Групи тварин & Дослідна 1 \\
\cline { 2 - 4 } & $4,0 \pm 0,07$ & $4,1 \pm 0,08$ & $4,0 \pm 0,06$ \\
Початкові величини & $4,1 \pm 0,09$ & $4,2 \pm 0,06$ & $4,2 \pm 0,08$ \\
1 доба & $4,4 \pm 0,10$ & $4,5 \pm 0,05$ & $4,5 \pm 0,07$ \\
5 доба & $3,8 \pm 0,09$ & $4,2 \pm 0,07 *$ & $4,4 \pm 0,10^{* *}$ \\
10 доба & $3,4 \pm 0,12$ & $4,2 \pm 0,10^{* * *}$ & $4,6 \pm 0,11^{* * *}$ \\
15 доба & $2,9 \pm 0,10$ & $4,0 \pm 0,11^{* * *}$ & $4,5 \pm 0,08^{* * *}$ \\
20 доба & $3,2 \pm 0,11$ & $4,0 \pm 0,09^{* * *}$ & $4,3 \pm 0,07^{* * *}$ \\
30 доба & & & \\
\hline
\end{tabular}

Аналогічні зміни спостерігаємо і при дослідженні рівня вітаміну А у крові бугайців контрольної та дослідних груп. За кадмієвого навантаження рівень вітаміну А у крові контрольної групи тварин на 15 і 20 доби досліду знизився відповідно на 16,3 і 22,5 \% відносно початкових величин.
Рівень вітаміну А у крові бугайців дослідних груп протягом усього досліду був високим. Так, на 15 добу досліду рівень вітаміну А у крові першої дослідної групи збільшився на 19,4 \%, а у крові другої дослідної групи - на 26,9% відносно контрольної групи тварин. 
Таблиця 2

Вплив метісевіту та ліпоінтерсилу на рівень вітаміну А у крові бугайців за хронічного кадмієвого токсикозу $(\mathrm{M} \pm \mathrm{m}, \mathrm{n}=5)$

\begin{tabular}{cccc}
\hline \multirow{2}{*}{ Час дослідження крові } & \multicolumn{3}{c}{ Вітамін Е (мкмоль/л) } \\
\cline { 2 - 4 } (доби) & Контрольна & Групи тварин & Дослідна 2 \\
\cline { 2 - 4 } & $0,80 \pm 0,030$ & $0,82 \pm 0,020$ & $0,85 \pm 0,024$ \\
Початкові величини & $0,81 \pm 0,024$ & $0,83 \pm 0,023$ & $0,86 \pm 0,031$ \\
1 доба & $0,83 \pm 0,015$ & $0,85 \pm 0,010$ & $0,88 \pm 0,019$ \\
5 доба & $0,74 \pm 0,020$ & $0,81 \pm 0,018^{*}$ & $0,89 \pm 0,023^{* *}$ \\
10 доба & $0,67 \pm 0,011$ & $0,80 \pm 0,030^{* *}$ & $0,85 \pm 0,019^{* * *}$ \\
15 доба & $0,62 \pm 0,035$ & $0,79 \pm 0,020^{* * *}$ & $0,86 \pm 0,027^{* * *}$ \\
20 доба & $0,69 \pm 0,018$ & $0,81 \pm 0,015^{* * *}$ & $0,85 \pm 0,021^{* * *}$ \\
30 доба &
\end{tabular}

При застосуванні ліпосомального препарату “Ліпоінтерсил” встановлено високий рівень вітаміну А на 20 і 30 доби досліду, де відповідно даний показник становив $0,86 \pm 0,027$ і 0,85 $\pm 0,021$ мкмоль/л.

Отже, застосування кормової добавки "Метісевіт" та ліпосомального препарату “Ліпоінтерсил” сприяли зростанню рівнів вітаміну А і Е. Підвищення вмісту даних показників вказує на активізацію неензимної ланки системи антиоксидантного захисту організму молодняку великої рогатої худоби за кадмієвого навантаження.

\section{Висновки}

Додаткове застосування ліпосомального препарату “Ліпоінтерсил” бугайцям за кадмієвого навантаження проявляє виражену позитивну дію на показники неензимної ланки системи антиоксидантного захисту, ніж при згодовуванні самої кормової добавки "Метісевіт", що вказує на необхідність їх сукупного застосування при усуненні такого виду інтоксикації. Кормова добавка "Метісевіт" і ліпосомальний препарат “Ліпоінтерсил” доповнюють призначену терапію і за умов сукупного застосування при кадмієвій інтоксикації проявляють високі антиоксидантні властивості.

\section{Подяка}

Ця робота була фінансово підтримана Міністерством освіти і науки України (0120U101999).

\section{References}

Ali, M. M., Murthy, R. C., \& Chandra, S. V. (1986). Developmental and longterm neurobehavioral toxicity of low-level in utero $\mathrm{Cd}$ exposure in rats. Neurobehavioral Toxicology and Teratology, 8(5), 463-468. URL: https:/www.ncbi.nlm.nih.gov/pubmed/ 3785508

Fregoneze, J. B., Marinho, C. A., Soares, T., Castro, L., Sarmento, C., Cunha, M., Gonzalez, V., Oliveira, P., Nascimento, T., Luz, C. P., Santana, Jr. P., DeOliveira, I. R., \& e-Castro-e-Silva, E. (1997). Lead $(\mathrm{Pb} 2+)$ and cadmium $(\mathrm{Cd} 2+)$ inhibit the dipsogenic action of central beta-adrenergic stimulation by isoproterenol. Brazilian Journal of Medical and Biologi- cal Research, 30(3), 419-423. doi: 10.1590/S0100879X1997000300018.

Gutyj, B. V., Binkevych, V., \& Binkevych, O. (2016). Hematological changes of rats after cadmium toxicosis. Scientific Messenger of LNU of Veterinary Medicine and Biotechnologies, 18(1), 165-167. URL: https://nvlvet.com.ua/index.php/journal/article/view/1 10 .

Gutyj, B. V., Murs'ka, S. D., Gufrij, D.F., Hariv, I. I., Levkivs'ka, N. D., Nazaruk, N. V., Gajdjuk, M. B., Pryjma, O. B., Bilyk, O. Ja., \& Guta, Z. A. (2016). Influence of cadmium loading on the state of the antioxidant system in the organism of bulls. Visnyk of Dnipropetrovsk University. Biology, ecology, 24(1), 96-102. doi: 10.15421/011611

Gutyj, B., Grymak, Y., Drach, M., Bilyk, O., Matsjuk, O., Magrelo, N., Zmiya, M., \& Katsaraba, O. (2017). The impact of endogenous intoxication on biochemical indicators of blood of pregnant cows. Regulatory Mechanisms in Biosystems, 8(3), 438-443. doi: 10.15421/021768.

Gutyj, B., Hufriy, D., Binkevych, V., Vischur, V., Binkevych, O., \& Kurlyak, I. (2015). The changes of biochemical and morphological indices of rats' blood under chronic cadmium toxicosis. Scientific Messenger of LNU of Veterinary Medicine and Biotechnologies, 17(3), 120-123. URL: https://nvlvet.com.ua/index.php/ journal/article/view/531.

Gutyj, B., Martyshchuk, T., Bushueva, I., Semeniv, B., Parchenko, V., Kaplaushenko, A., Magrelo, N., Hirkovyy, A., Musiy, L., \& Murska, S. (2017). Morphological and biochemical indicators of blood of rats poisoned by carbon tetrachloride and subject to action of liposomal preparation. Regulatory Mechanisms in Biosystems, 8(2), 304-309. doi: 10.15421/021748.

Gutyj, B.V., Gufrij, D., Binkevych, V., Binkevych, O., Kurlyak, I., \& Sobolta, A. (2015). Influence of Mevesel \& E-selenium on level of intermediate and final products of lipid peroxidation in bulls' blood after cadmium loading. Scientific Messenger of LNU of Veterinary Medicine and Biotechnologies, 17(1), 190-194. URL: https://nvlvet.com.ua/index.php/ journal/article/view/292.

Honskyy, Ya. I., Yastremskaya, S. O., \& Boychuk, B. R. (2001). Vikovi osoblyvostsi porushennya peroksydnoho okyslennya lipidiv i aktyvnosti enerhozabezpechuvalnyh fermentiv pry kadmiyeviy 
intoksykatsiyi [Age features breach of lipid peroxidation and activity of enzymes in utility cadmium intoxication] Medichna chimiya - Medical Chemistry, 3(1), 16-19 (in Ukrainian).

Hutyi, B. V. (2013). Riven pokaznykiv nefermentnoi systemy antyoksydantnoho zakhystu orhanizmu bychkiv za umov kadmiievoho navantazhennia. Naukovyi visnyk Lvivskoho natsionalnoho universytetu veterynarnoi medytsyny ta biotekhnolohii im. Gzhytskoho, 15, 1(4), 40-45. URL: http://nbuv.gov.ua/UJRN/nvlnu_2013_15_1(4)_10 (in Ukrainian).

Hutyi, B. V. (2013). Vmist vitaminiv A i E u krovi bychkiv za umov kadmiievoi intoksykatsii. Visnyk Sumskoho natsionalnoho ahrarnoho universytetu. Seriia: Veterynarna medytsyna, 2, 31-33. URL: http://nbuv.gov.ua/UJRN/Vsna_vet_2013_2_10 (in Ukrainian).

Hutyi, B. V. (2013). Vplyv E-selenu na aktyvnist hlutationovoi systemy antyoksydantnoho zakhystu orhanizmu buhaitsiv pry kadmiievomu navantazhenni. Visnyk Sumskoho natsionalnoho ahrarnoho universytetu. Seriia: Veterynarna medytsyna. 9, 70-73. URL: http://nbuv.gov.ua/UJRN/Vsna_vet_2013_9_22 (in Ukrainian)

Hutyi, B. V. (2013). Vplyv E-selenu na vmist vitaminiv A i E u krovi bychkiv za umov kadmiievoi intoksykatsii. Naukovyi visnyk Lvivskoho natsionalnoho universytetu veterynarnoi medytsyny ta biotekhnolohii im. Gzhytskoho, 15, 3(3), 311-314. URL: http://nbuv.gov.ua/UJRN/nvlnu $2013 \quad 15 \quad 3(3) \quad 55$ (in Ukrainian).

Hutyi, B. V. (2013). Vplyv khlorydu kadmiiu u riznykh dozakh na aktyvnist aminotransferaz syrovatky krovi buhaitsiv. Naukovyi visnyk Lvivskoho natsionalnoho universytetu veterynarnoi medytsyny ta biotekhnolohii im. Gzhytskoho, 15, 1(1), 49-52. URL: http://nbuv.gov.ua/UJRN/nvlnu $2013 \quad 15$ 1(1) 11 (in Ukrainian).

Hutyi, B. V. (2013). Vplyv khlorydu kadmiiu u toksychnykh dozakh na hlutationovu systemu antyoksydantnoho zakhystu orhanizmu bychkiv. Veterynarna biotekhnolohiia, 22, 112-116. URL: http://nbuv.gov.ua/UJRN/vbtb_2013_22_23 (in Ukrainian).

Hutyi, B. V. (2013). Vplyv Meveselu na pokaznyky neenzymnoi systemy antyoksydantnoho zakhystu orhanizmu buhaitsiv za umov kadmiievoho navantazhennia. Biolohiia tvaryn, 15(3), 16-21. URL: http://nbuv.gov.ua/UJRN/bitv_2013_15_3_4 (in Ukrainian).

Hutyi, B. V. (2013). Vplyv meveselu na vmist vitaminiv A i E u krovi bychkiv za umov kadmiievoi intoksykatsii. Naukovyi visnyk Lvivskoho natsionalnoho universytetu veterynarnoi medytsyny ta biotekhnolohii im. Gzhytskoho, 15, 3(1), 78-82. URL: http://nbuv.gov.ua/UJRN/nvlnu $2013 \quad 15 \quad 3(1) \quad 18$ (in Ukrainian).

Hutyi, B. V. (2013). Vplyv meveselu ta E-selenu na riven pokaznykiv ne fermentnoi systemy antyoksydantnoho zakhystu orhanizmu buhaitsiv pry kadmiievomu navantazhenni. Veterynarna medytsyna, 97, 419-421. URL: http://nbuv.gov.ua/UJRN/vetmed 201397172 (in Ukrainian).

Khariv, M., Gutyj, B., Butsyak, V., \& Khariv, I. (2016). Hematological indices of rat organisms under conditions of oxidative stress and liposomal preparation action. Biological Bulletin of Bogdan Chmelnitskiy Melitopol State Pedagogical University, 6(1), 276-289. doi: 10.15421/201615.

Lavryshyn, Y. Y., Gutyj, B. V., Leskiv, K. Y., Hariv, I. I., Yevtukh, L. H., \& Shnaider, V. L. (2020). Influence of cadmium on the cellular part of the immune system of young cattle. Ukrainian Journal of Veterinary and Agricultural Sciences, 3(2), 47-52. doi: 10.32718/ujvas3-2.08.

Lavryshyn, Y., Gutyj, B., Leskiv, Ch., Kalyn, B., Holub, O., \& Romanovych, M. (2020). The effect of Cadmium on the level of vitamins A and E in the blood of young cattle. Colloquium-journal, 32(84), 11-15.

Liu, J., Qian, S.Y., Guo, Q., Jiang, J., Waalkes, M.P., Mason, R.P., \& Kadiiska, M.B. (2008). Cadmium generates reactive oxygen- and carbon-centered radicalspecies in rats: Insights from in vivo spintrappingstudies. Free Radic Biol Med., 45(4), 475481. doi: 10.1016/j.freeradbiomed.2008.04.041.

Lu, J., Jin, T., Nordberg, G., \& Nordberg, M. (2005). Metallothionein gene expression in peripheral lymphocytes and renal dysfunction in a population environmentally exposed to cadmium. Toxicol Appl Pharmacol 206(2), 150-156. doi: 10.1016/j.taap.2004.12.015.

Martyshuk, T. V., Gutyj, B. V., \& Vishchur, O. I. (2016). Level of lipid peroxidation products in the blood of rats under the influence of oxidative stress and under the action of liposomal preparation of " $\mathrm{Bu}$ taselmevit", Biological Bulletin of Bogdan Chmelnitskiy Melitopol State Pedagogical University, 6(2), 22-27. doi: 10.15421/201631.

Nazaruk, N., Gutyj, B.V., \& Hufriy, D. (2015). Influence of metifen and vitamix se on the activity of aminotransferases of bulls blood serum at cadmium nitrate loading. Scientific Messenger of LNU of Veterinary Medicine and Biotechnologies, 17(1), 121126. URL: https://nvlvet.com.ua/index.php/journal/ article/view/231.

Ostapyuk, A. Y., \& Gutyj, B. V. (2020). Influence of milk thistle, methifene and sylimevit on the morphological parameters of laying hens in experimental chronic cadmium toxicosis. Ukrainian Journal of Veterinary and Agricultural Sciences, 3(1), 42-46. doi: 10.32718/ujvas3-1.08.

Pavan Kumar, G., \& Prasad, M. N. V. (2004). CadmiumInducible Proteins in Ceratophyllum demersum L. (a Fresh Water Macrophyte): Toxicity Bioassays and Relevance to Cadmium Detoxification. Bulletin of Environmental Contamination and Toxicology, 73(1), 174-181. doi: 10.1007/s00128-004-0410-4.

Peng, L., Wang, X., Huo, X., Xu, X., Lin, K., Zhang, J., Huang, Y., \& Wu, K. (2015). Blood cadmium burden and the risk of nasopharyngeal carcinoma: a casecontrol study in Chinese Chaoshan population. Envi- 
ronmental Science and Pollution Research, 22(16), 12323-12331. doi: 10.1007/s11356-015-4533-4.

Rodríguez, E. M., Bigi, R., Medesani, D. A., Stella, V. S., Greco, L. S. L., Moreno, P. A. R., Monserrat, J. M., Pellerano, G. N., \& Ansaldo, M. (2001). Acute and chronic effects of cadmium on blood homeostasis of an estuarine crab, Chasmagnathus granulata, and the modifying effect of salinity. Brazilian Journal of Medical and Biological Research, 34(4), 509-518. URL: https://www.ncbi.nlm.nih.gov/pubmed/11285463.

Salvatori, F., Talassi, C. B., Salzgeber, S. A., Sipinosa, H. S., \& Bernardi, M. M. (2004). Embryotoxic and longterm effects of cadmium exposure during embryogenesis in rats. Neurotoxicology and Teratology, 26(5), 673-680. doi: 10.1016/j.ntt.2004.05.001.

Slobodian, S. O., Gutyj, B. V., \& Leskiv, K. Y. (2019). The level of lipid peroxidation products in the rats blood under prolonged cadmium and lead loading. Ukrainian Journal of Veterinary and Agricultural Sciences, 2(3), 15-18. doi: 10.32718/ujvas2-3.04.
Slobodian, S. O., Gutyj, B. V., \& Murska, S. D. (2020). Effect of sodium selenite and feed additive "Metisevit plus" on morphological parameters of blood of rats at the intoxication of Cadmium and Lead. Scientific Messenger of Lviv National University of Veterinary Medicine and Biotechnologies. Series: Veterinary sciences, 22(97), 52-57. doi: 10.32718/nvlvet9710.

Uetani, M., Kobayashi, E., Suwazono, Y., Okubo, Y., Honda, R., Kido, T., \& Nogawa, K. (2005). Selenium, Cadmium, Zinc, Copper, and Iron Concentrations in Heart and Aorta of Patients Exposed to Environmental Cadmium. Bulletin of Environmental Contamination and Toxicology, 75(2), 246-250. doi: 10.1007/s00128-005-0744-6.

Vlizlo, V. V. (2012). Laboratorni metody doslidzhen u biolohiyi, tvarynnytstvi ta veterynarniy medytsyni [Laboratory methods of investigation in biology, stock-breeding and veterinary]. Spolom, Lviv (in Ukrainian). 